\title{
Cyprinid fauna (Cypriniformes) of River Panjkora, district Lower Dir, Khyber Pakhtunkhwa, Pakistan
}

\author{
Abdul Wahab* and Ali Muhammad Yousafzai \\ Department of Zoology, Islamia College University Peshawar-Pakistan \\ *Corresponding author's email: wahabzoologist@gmail.com \\ Citation
}

Abdul Wahab* and Ali Muhammad Yousafzai. Cyprinid fauna (Cypriniformes) of River Panjkora, District Lower Dir, Khyber Pakhtunkhwa, Pakistan. Pure and Applied Biology. Vol. 6, Issue 4, pp1354-1365.

http://dx.doi.org/10.19045/bspab.2017.600146

\begin{tabular}{llll}
\hline \hline Received: 19/07/2017 & Revised: 18/10/2017 & Accepted: 21/10/2017 & Online First: 26/10/2017 \\
\hline \hline
\end{tabular}

\section{Abstract}

This study was conducted to assess Ichthyodiversity of family Cyprinidae in River Panjkora from January 2012 to December 2015. A total of 671 specimens representing 7 genera and 10 species were collected. Species collected were Barilius pakistanicus, Barilius vagra, Tor putitora, Crossocheilus diplocheilus, Garra gotyla, Schizothorax labiatus, Schizothorax esocinus, Schizothorax plagiostmus, Carassius auratus and Cyprinus carpio. Schizothorax plagiostmus was found to be the most abundant species with a relative density (RD) of 21.01 and relative frequency (RF) of 13.04. It was the only species qualifying the criterion to be ranked as eury species. Schizothorax esocinus was rare in the study area with a RD 0.45 and RF 2.17.

Keywords: Cyprinidae; Schizothorax; River Panjkora; Eury species; Relative density; Relative frequency

\section{Introduction}

Pisces make one of the important groups of vertebrates inhabiting almost all water bodies from freshwaters to brackish and up to marine ecosystems [1]. Man, is consuming fish as food since the prehistoric ages. Ichthyofauna plays a vital role in aquatic habitats as it mostly dominates the biotic components in terms of number [2].

In Fish Base total number of fish species listed are 28900, in which 13000 are fresh water fishes. Fresh water fishes are found in lakes, streams and river which cover only 1 $\%$ of the earth surface [3]. From Sagar lake Madhya Pradesh, India, 21 fresh water fish species were reported [4]. In a study at Vattakkayal Kolloam District, Kerala, India, 22 fish species were documented and ranked as critically endangered, vulnerable and as lower risk level [5]. From River Charju Arunachal Pradesh, India 16 species of family Cyprinidae were reported [6]. It was reported that introduction of exotic fish in Iberia, resulted in the extinction of some native fish species [7]. From Tamor River, Himalayan region, Nepal 30 fresh water fish species were collected in which $61 \%$ fish species belonged to family Cyprinidae [8]. Total fish species reported from Similipal Biosphere Reserve were 66. In a study out of 66 species 29 species were of family Cyprinidae [9]. From Tons River India 15 fresh water species were documented [10]. Increased ichthyofaunal similarities in some localities of Australia were found to be the result of anthropogenic influences [11]. From Rajshahi District, Bangladesh 133 fresh water fish species were collected [12]. During a study on 
Family Cyprinidae, 24 species were reported from Coorg District Karnataka, India [13]. From Tinau River Nepal 35 fish species were documented in which $81.73 \%$ were of family Cyprinidae [14]. Family Cyprinidae was found to be the dominant family in Uttarakhand, India from where 19 fresh water species were collected [15]. From River Ramganga Central Himalaya, India 11 fish species of family Cyprinidae were documented [16]. In a study on the distribution of fresh water species in Pakistan 86 fish species were reported [17]. From River Kabul at District Nowshera 14 fresh water species of family Cyprinidae were reported [18]. From Hub reservoir Sindh 21 fresh water fish species belonging to 9 families and 7 orders were documented [19]. From Mighty Indus 180 species were reported [20]. From River Jhelum 51 fish species were collected, in which 25 were of family Cyprinidae. It was further enumerated that low population density of endemic species was due to the introduction of exotic species i.e. Oreochromis aureus [21]. From River Zhob, Baluchistan 6 species of family Cyprinidae were collected [22]. From River Swat at Charsadda, 20 fish species of family Cyprinidae were documented [23]. From River Swat 10 fresh water fish species of family Cyprinidae were collected. Major threats to ichthyofaunal were found to be the use of explosive and electricity for fish hunting [24]. Family Cyprinidae with a total of 9 species was documented from different streams of Bajaur agency [25]. Eleven fresh water fishes were collected from Konhaye stream, a tributary of River Panjkora, District Lower Dir [26]. From River Panjkora, District Dir Upper, 11 fish species were collected. Richest family in the area was found to be the Cyprinidae [27]. In the present study Schizothorax plagiostomus was found to be the most dominant species in the study area. The study area is mostly unexplored for ichthyofaunal diversity and present study will provide a baseline of information in this regard.

\section{Materials and methods \\ Study area}

District Dir Lower is situated in the Northern part of Khyber Pakhtunkhwa. It has District Dir Upper in North, District Swat in East, District Malakand in South and Bajaur in West. The name of River Panjkora refers to its origin from five streams i.e. Kumrat-Kohistan, Lawari, Barawal, Usherai and Guladai. River Panjkora begins from Hindukash range at latitude, $35^{\circ} 45$ and passes through North and south faces making it through several tributaries i.e. Dir, Barawal, Usheri, Nihagdara, Konai, Roade, Guladai, Rabat, Toormang, Narhan and Karo. River Panjkora join River Swat at Busak near Qulangi (Figure 1). The study area of the river is about 180 kilometers from its origin. The area is about 70 kilometers from Rabat to Busak. It lies between latitude of $34^{0} 38$ and $34^{0} 84$ towards north having average altitude of 725 to 850 meters on the bank of River Panjkora.

\section{Collection and identification}

A total of six monitoring sites i.e. Rabat, Odigram, Timergara, Khazana, Shagu kas and Busak were established for sampling. Fish samples were collected by cast net, hand net, fishing rods and by hands in shallow water. Samples were taken to laboratory and shifted to plastic jars. Large sized samples were incised and 10\% formalin was used as a preservative [28]. Morphometric measurements of each fish sample were recorded and tabulated [28, 29]. Identification was done following standard keys i.e. [28-31]. 


\section{Quantitative attributes}

Quantitative attributes were calculated according to following formulae.

$$
\begin{aligned}
& \text { Density }=\frac{\text { Number of fish samples of a species collected from all monitoring sites }}{\text { Total monitoring sites }} \\
& \text { Relative Density }=\frac{\text { Density of a particular fish species }}{\text { Total densities of all fish species }} \quad \text { X } 100 \\
& \text { Frequency }=\frac{\text { Number of monitoring sites at which a fish species was found }}{\text { Total number of monitoring sites }} \times 100 \\
& \text { Relative Frequency }=\frac{\text { Frequency of a particular fish species }}{\text { Total frequencies of all fish species }} \times 100
\end{aligned}
$$

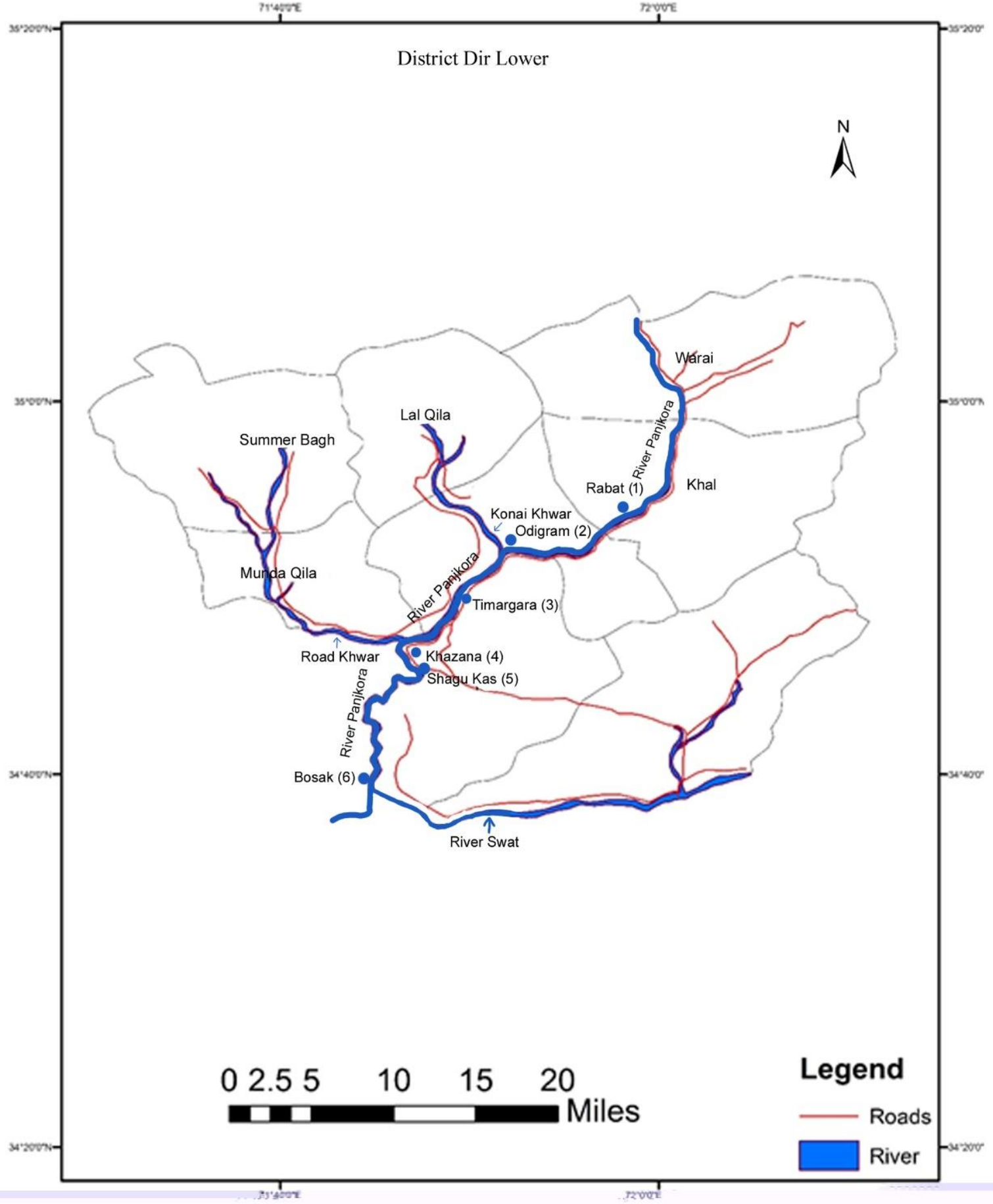

Figure 1. Map of the study area 


\section{Results and discussion}

A total of 671 specimens representing 10 species under 7 genera of the family Cyprinidae were collected. Taxonomic and morphometric details (Table 1 and 2) of fish species collected are as follows:

\section{Barilius pakistanicus (Mirza \& Sadiq, 1978)}

\section{Colour}

It was silvery in colour having bars which descended from the back to lateral line area as well as below. Mostly found in shallow waters but also found in deep waters.

\section{Morphometric measurments}

Total length of this fish was recorded as 9.2 $\mathrm{cm}$ with a fork length of $8.5 \mathrm{~cm}$ and with a standard length of $7.7 \mathrm{~cm}$. It had an eye diameter and snout length of $0.5 \mathrm{~cm}$ respectively. Body depth was measured as $1.7 \mathrm{~cm}$. Its lateral line scale count was 42 . It was collected from only two monitoring sites i.e. Konai and Road stream. Its population density was found to be 15.67 while its frequency was 33.33, which reflects its limited range of ecological tolerance (Plate 1, Figure 1).

\section{Ecology}

Its relative density was 14.01 and relative frequency was 4.35. This species was reported from Afghanistan [32].

\section{Distribution}

In a review this species was documented from Khyber Pakhtunkhwa, Punjab, Sindh, Azad Jammu Kashmir and Baluchistan [17]. This species was reported from different localities of Pakistan i.e. from River Jhelum [21], from Dera Ghazi Khan [33], from River Kabul at Nowshera [18], from Attock [34], from Kalpani stream Mardan [35], from River Swat at Charsada [23], from River Swat [24], from Aronai stream Swat [36] and from River Barandu Buner [37]. It is important to mention that this species was found as a dominant in River Chamla Buner in a previous study [38].

\section{Barilius vagra (Hamilton, 1822) Colour}

It was silvery in colour with bluish vertical bars, descending from back but not reaching the lateral line. Fins were yellowish to pink. Mostly found in shallow water with gravely and rocky bottom.

\section{Morphometric measurements}

Total, fork and standard lengths were recorded as 4.9, 4.5 and $3.9 \mathrm{~cm}$ respectively. It had eye diameter and snout length of $0.3 \mathrm{~cm}$. Its lateral line scale count was 43. It was collected from two monitoring sites i.e. Konai (Odigram) and Roade (Khazana) stream.

\section{Ecology}

Its population density was 6.33 while its frequency was 33.33 , which clearly shows its limited ecological range of tolerance (Plate 1, Figure 2). Its relative density was 5.66 while its relative frequency was 4.35 .

\section{Distribution}

This species was recorded from abroad i.e. from W. Ramganga Central Himalaya India [16], from Uttarkhand, India [15], from Northeast India [39] and from Nepal [8]. Baralius vagra was reported from different localities of Pakistan, such as from River Zhob, Baluchistan [22], from Dera Ghazi Khan [33], from River Jhelum [21], from River Kabul at Nowshera [18], from Attock [34], from Kalpani stream Mardan [35] and from River Swat at Charsada [23].

\section{Tor putitora (Hamilton, 1822)}

\section{Colour}

Its dorsal side was greenish; sides light pink and ventral side was silvery white. Fins colour was reddish yellow. Mostly found in rapids of river with rocky bottom.

\section{Morphometric measurements}

Total length of the fish was recorded as 18.8 $\mathrm{cm}$, fork length $16.7 \mathrm{~cm}$ and standard length as $15 \mathrm{~cm}$. It had an eye diameter of $0.8 \mathrm{~cm}$ and snout length of $1.5 \mathrm{~cm}$. Body depth was measured as $3.6 \mathrm{~cm}$ and lateral line scale count was 42 . It was collected from five monitoring sites. 


\section{Ecology}

Its population density was 4.5 while its frequency was 83.33. Its low density shows that this species is under severe biotic and abiotic stresses, while its high frequency reflects that its ecological range of resistance is wide (Plate 1, Figure 3). Its relative density was 4.02 and relative frequency was 10.87 .

\section{Distribution}

Tor putitora appears in reports from abroad i.e. from River Ravi and Chanab India [40], from Afghanistan [32], from Ramganga Central Himalaya, India [16], from Uttarakhand India [15], from River Channab, Jammu and Kashmir [41], from Northeast India [39], from River Charju, India [6] and from Garo Hills, India [42]. Tor putitora was reported from different parts of Pakistan i.e. from Khyber Pakhtunkhwa, Azad Jammu Kashmir, Punjab, Baluchistan and Sindh [17], from River Jhelum [21], from Attock [33], from Kalpani stream Mardan [35], from River Kabul at Nowshehra [18], from River Barandu Buner [37], from River Chamla, Buner [38], from River Swat [24] and from River Swat at Charsada.

\section{Crossocheilus diplocheilus (Heckel, 1838) Colour}

Its dorsal side was greyish and ventral side pinkish yellow. Mostly found in shallow water with rocky bottom.

\section{Morphometric measurements}

Its total length was recorded as $12.7 \mathrm{~cm}$, fork length 11.6 and standard length as 10.5 $\mathrm{cm}$. Its eye diameter, snout length and body depth was measured as $0.5 \mathrm{~cm}, 1.1 \mathrm{~cm}$ and $3 \mathrm{~cm}$ respectively. Its lateral line scale count was 38. It was collected from five monitoring sites (Plate 1, Figure 4).

\section{Ecology}

Its population density was 13 while its frequency was 100 . Its low density shows that this species is under severe biotic and abiotic stresses, while its high frequency reflects that its ecological range of resistance is wide. Its relative density was 11.62 and relative frequency was 13.04.

\section{Distribution}

This species was reported from Lidder River Kashmir India [43]. Within Pakistan Crossocheilus diplocheilus was documented from Zhob, Balochistan [22], from Attock [34], from River Jhelum [21], from Dera Ghazi khan [33], from River Kabul at Nowshera [18], River Kabul at Machini [44], from Aronai stream Swat [36], from River Swat [24] and from Konhaye stream Dir Lower [26].

\section{Garra gotyla (Gray, 1830)}

\section{Colour}

Back side was brownish olive and lower side was greyish white. Dots were found on dorsal fin while other fins were light pink in colour. It is found in stream and river of hilly areas. It prefers water with slow speed and bottom with large stones.

\section{Morphometric measurements}

Total length of the fish was recorded as 19.2 $\mathrm{cm}$, with a fork length of $18 \mathrm{~cm}$ and standard length of $16.5 \mathrm{~cm}$. Diameter of eye was recoded as $0.5 \mathrm{~cm}$ and snout length of $2 \mathrm{~cm}$. Body depth was measured as $3 \mathrm{~cm}$. Its lateral line scale count was 30 . It was collected from all the six monitoring sites.

\section{Ecology}

Its population density was 17.17 while its frequency was 100, which reflects that it is abundant in the study area (Plate 1, Figure 5). Its relative density was 15.35 while its relative frequency was 13.04 .

\section{Distribution}

This species was documented from abroad such as from Uttarkhand, India [15], from Ramganga Central Himalaya, India [16] and River Charju India [6]. Garra gotyla was also reported by many workers from different localities of Pakistan i.e. from River Jhelum [21], from Dera Ghazi Khan [33], from River Zhob, Baluchistan [22], from River Kabul at Nowshera [18], from Kalpani stream Mardan [35], from River Swat [38], from River Swat at Charsada [23], from Attock [34], from River Chamla Buner [38] and from Konhaye stream Dir Lower [26]. This species was the $3^{\text {rd }}$ most abundant species in the study area. 
Schizothorax labiatus (McClelland, 1842) Colour

It was greyish brown on back and yellowish below. Dorsal and caudal fins were greyish and other fins were pinkish. It is found in rapids of stream and river.

\section{Morphometric measurements}

Total, fork and standard lengths were recorded as 32, 29 and $26.5 \mathrm{~cm}$ respectively. It had eye diameter of $0.9 \mathrm{~cm}$ and snout length of $2.9 \mathrm{~cm}$. Body depths was measured as $6.1 \mathrm{~cm}$. Its lateral line scale count was 110 .

\section{Ecology}

It was collected from all the six collection sites. Its population density was 18.83 while its frequency was 100 , which reflects that it is abundant in the study area (Plate 1, Figure 6). Its relative density was 15.35 and its relative frequency was 13.04.

\section{Distribution}

The species was reported from other countries i.e. from Afghanistan [32], from Lidder River, Kashmir [43], from Nepal [8] and from Himalaya, India [45]. In Pakistan this species was reported from AJK, Khyber Pakhtunkhwa, Punjab, Baluchistan and Gilgit Baltistan [17], from Attock [34], from River Swat at Charsada [23], from River Swat [24] and from Konhaye stream Dir Lower [26]. From Chashma it was reported for the first time [46]. This species appeared to be the $2^{\text {nd }}$ most abundant species in the study area.

\section{Schizothorax esocinus Heckel, 1838 \\ Colour}

Its colour was silver on back having black spots and lower side was white. It is found in stream and river with rapidly flowing water.

\section{Morphometric measurements}

Total fork and standard lengths were recorded as 25, 23 and $20.5 \mathrm{~cm}$ respectively. Head length was measured as $5.6 \mathrm{~cm}$. It had eye diameter of $0.7 \mathrm{~cm}$ and snout length of $2.2 \mathrm{~cm}$. Its lateral line scale count was 97 . Only three specimens were collected at Busak (Qulangi).

\section{Ecology}

Its population density was 0.5 while its frequency as 16.67 . It shows that it is very rare in the studying area (Plate 1, Figure 7). Its relative density was 0.45 while relative frequency was 2.17.

\section{Distribution}

Schizothorax esocinus was documented from Afghanistan [32], from Lidder River Kashmir [43] and from Northeast India [39]. Within Pakistan this species was reported from AJK, Khyber Pakhtunkhwa, Northern Punjab and Gilgat Baltistan [17], from River Swat [24], from River Darmai Upper Swat [47], from River Panjkora, Dir Upper [48] and from Konhaye stream Dir Lower [26]. This species was found to be rare in the study area.

\section{Schizothorax plagiostomus Heckel, 1838 Colour}

It was silvery greyish in colour and fins were pinkish. It is found in mountains streams and rivers.

\section{Morphometric measurements}

Total length was recorded as $32.1 \mathrm{~cm}$, fork length of 29.8 while standard length of 27.4 $\mathrm{cm}$. Diameter of eye was $0.8 \mathrm{~cm}$ and snout length of $2.4 \mathrm{~cm}$. Body depths was $5 \mathrm{~cm}$. Its lateral line scale count was 110. It was collected from all the six monitoring sites.

\section{Ecology}

Its population density was 23.5 and frequency was 100 . Its density and frequency reflects that it is the most abundant species in the studying area (Plate 1, Figure 8). Its relative density was 21.01 and relative frequency was 13.04.

\section{Distribution}

This species was reported from abroad i.e. from Afghanistan [32], from Ramganga Central Himalayan, India [16], from Utterkhand, India [15], from Lidder River Kashmir [43], from Kashmir Himalaya, India [49], from Northeast India [39] and from Nepal [8]. This species was also reported from different localities of Pakistan i.e. from Northern Baluchistan, Norhern Punjab, Khyber Pakhtunkhwa, AJK and Gilgat Baltistan [17], from River Jhelum [21], from Dera Ghazi Khan [33], 
from Allai Khoar Batagram [50], from River Zhob, Baluchistan [22], from Aronai stream Swat [36], from River Swat at Charsada [23] and from River Panjkora District Dir Upper [27].This species appeared to be the dominant species in River Darmai Upper Swat [47]. The presence of Schizothorax plagiostomus in a wide range of freshwater habitats establishes its status as a Eury species.

\section{Carassius auratus (Linnaeus, 1758) \\ Colour}

The fish was greyish brown in colour. It is found in stream and rivers. It is also kept as aquatic pet in aquarium.

\section{Morphometric measurements}

Total, fork and standard length were recorded as 19.5, 18 and $15.5 \mathrm{~cm}$ respectively. It had eye diameter of $0.9 \mathrm{~cm}$ and snout length of $1.3 \mathrm{~cm}$. Its body depths was $5.5 \mathrm{~cm}$ while lateral line scale count was 28 . It was collected from all monitoring sites.

\section{Ecology}

Its population density was 7 while frequency was 100, which shows its wide ecological range (Plate 1, Figure 9). Its relative density was 6.25 and relative frequency was 13.04.

\section{Distribution}

This species was reported from Lidder River Kashmir, India [43]. In Pakistan this species was documented from Khyber Pakhtunkhwa, AJK, Punjab, Sindh and Baluchistan [17], from Taunsa and Chasma reservoirs, Punjab [51], from Attock [34], from Kalpani Mardan [35], from River Kabul at Nowshehra [18], from River Swat District Swat [24], from River Swat at Charsada [23] and from River Panjkora District Dir Upper [27].

\section{Cyprinus carpio Linnaeus, 1758}

\section{Colour}

Its colour was greenish brown. It is found in stream and river.

\section{Morphometric measurements}

Its total, fork and standard length were recorded as 29, 26.5 and $24.1 \mathrm{~cm}$ respectively. It had eye diameter of $1 \mathrm{~cm}$ and snout length of $3 \mathrm{~cm}$. Body depths was measured as $8.6 \mathrm{~cm}$. Its lateral line scale count was 36. It was collected from all monitoring sites.

\section{Ecology}

Its density was 5.33 while frequency was 100, which shows its wide ecological range of tolerance (Plate 1, Figure 10). Its relative density was 4.77 and relative frequency as 13.04.

\section{Distribution}

This species was reported from Afghanistan [32] and Northeast India [39]. Within Pakistan this species was reported from Sindh, Khyber Pakhtunkhwa, Punjab, Azad Jammu Kashmir and Baluchistan [17], from Attock [34], from Kalpani stream Mardan [35], from River Jhelum [21], from Taunsa and Chasma reservoirs Punjab [51], from River Kabul at Nowshera [18], from River Swat at Charsada [23], from Aronai stream Swat [36], from River Swat [24] and from Konhaye stream Dir Lower [26]. 
Table 1. Morphometric details of Cyprinidae species of River Panjkora, Pakistan

\begin{tabular}{|c|c|c|c|c|c|c|c|c|c|c|c|c|c|c|c|c|c|}
\hline $\begin{array}{l}\text { S. } \\
\text { No }\end{array}$ & & $\begin{array}{l}\text { Wt- } \\
\text { gm }\end{array}$ & $\begin{array}{l}\text { TL- } \\
\mathrm{cm}\end{array}$ & $\begin{array}{l}\text { FL- } \\
\mathrm{cm}\end{array}$ & $\begin{array}{l}\text { SL- } \\
\mathrm{cm}\end{array}$ & $\begin{array}{c}\mathrm{BD}- \\
\mathrm{cm}\end{array}$ & $\begin{array}{l}\text { ED- } \\
\mathrm{cm}\end{array}$ & $\begin{array}{c}\text { PcFL- } \\
\mathrm{cm}\end{array}$ & $\begin{array}{c}\text { PIFL- } \\
\mathrm{cm}\end{array}$ & $\begin{array}{c}\text { DFL- } \\
\mathrm{cm}\end{array}$ & $\begin{array}{l}\text { AF- } \\
\mathrm{cm}\end{array}$ & $\begin{array}{c}\text { CFL- } \\
\mathrm{cm}\end{array}$ & $\begin{array}{c}\mathrm{HL}- \\
\mathrm{cm}\end{array}$ & $\begin{array}{c}\text { LJL- } \\
\mathrm{cm}\end{array}$ & $\begin{array}{c}\text { UJL- } \\
\mathrm{cm}\end{array}$ & $\begin{array}{c}\text { SnL- } \\
\mathrm{cm}\end{array}$ & $\begin{array}{c}\text { Mga- } \\
\mathrm{cm}\end{array}$ \\
\hline 1 & $\begin{array}{c}\text { Barilius pakistanicus Mirza } \\
\text { \& Sadiq, } 1978\end{array}$ & 8 & 9.2 & 8.5 & 7.7 & 1.7 & 0.5 & 1.25 & 1 & 1.2 & 1.2 & 1.5 & 1.7 & 0.75 & 0.85 & 0.5 & 0.6 \\
\hline 2 & $\begin{array}{c}\text { Barilius vagra (Hamilton, } \\
1822)\end{array}$ & 2 & 4.9 & 4.5 & 3.9 & 0.8 & 0.3 & 0.75 & 0.65 & 0.7 & 0.7 & 1 & 1 & 0.35 & 0.5 & 0.3 & 0.4 \\
\hline 3 & $\begin{array}{c}\text { Tor putitora (Hamilton, } \\
1822 \text { ) }\end{array}$ & 70 & 18.8 & 16.7 & 15 & 3.6 & 0.8 & 2.7 & 2.3 & 3.4 & 2.5 & 3.4 & 4.2 & 1.4 & 1.5 & 3.6 & 1.3 \\
\hline 4 & $\begin{array}{c}\text { Crossocheilus diplocheilus } \\
\text { (Heckel, 1838) }\end{array}$ & 23 & 12.7 & 11.6 & 10.5 & 3 & 0.5 & 1.8 & 1.7 & 2.1 & 1.6 & 2.1 & 2.2 & 0.7 & 0,8 & 1.1 & 1 \\
\hline 5 & Garra gotyla (Gray, 1830) & 72 & 19.2 & 18 & 16.5 & 3 & 0.5 & 3 & 3 & 3.3 & 2.9 & 3.3 & 3.5 & 1.1 & 1.3 & 2 & 1.7 \\
\hline 6 & $\begin{array}{l}\text { Schizothorax labiatus } \\
\text { (McClelland, 1842) }\end{array}$ & 385 & 32 & 29 & 26.5 & 6.1 & 0.9 & 4.8 & 4.3 & 4.3 & 4.8 & 5.5 & 6.7 & 2 & 2 & 2.9 & 2.4 \\
\hline 7 & $\begin{array}{c}\text { Schizothorax esocinus } \\
\text { Heckel, } 1838 \\
\end{array}$ & 130 & 25 & 23 & 20.5 & 4.2 & 0.7 & 3.5 & 3.3 & 4.2 & 3.7 & 4,4 & 5.6 & 3 & 4 & 2.2 & 1.9 \\
\hline 8 & $\begin{array}{c}\text { Schizothorax } \\
\text { Plagiostomus Heckel, } 1838\end{array}$ & 376 & 32.1 & 29.8 & 27.4 & 5 & 0.8 & 4.7 & 4.7 & 4.4 & 5.2 & 5.8 & 5.6 & 1.2 & 2 & 2.4 & 2.6 \\
\hline 9 & & 145 & 19.5 & 18 & 15.5 & 5.5 & 0.9 & 3.1 & 3.3 & 2.9 & 2.7 & 3.9 & 4.4 & 1.1 & 1.3 & 1.3 & 1.3 \\
\hline 10 & $\begin{array}{c}\text { Cyprinus carpio Linnaeus, } \\
1758 \\
\end{array}$ & 430 & 29 & 26.5 & 24.1 & 8.6 & 1 & 3.9 & 4 & 4.2 & 3.9 & 6 & 7.1 & 2 & 2.8 & 3 & 4.3 \\
\hline
\end{tabular}

\section{Key to the abbreviations}

Wt-Weight in grams, TL-Total length, FL-Fork length, SL-Standard length, BD-Body depth, ED-Eye diameter, PcFL-Pectoral fin length, PIFL-Pelvic fin length, DFL-Dorsal fin length, AF-Anal fin length, CFL-Caudal fin length, HL-Head length, LJL-Lower jaw length, UJL-Upper Jaw length, SnL-Snout length, Mga-Mouth gap

Table 2. Presence-Absence data of Ichthyofauna of River Panjkora, District Lower Dir, Pakistan

\begin{tabular}{|c|c|c|c|c|c|c|c|c|c|c|c|}
\hline S. No & Taxon & Rabat & Odigram & Timergara & Khazana & Shagukas & Busak & Density & Frequency & $\begin{array}{l}\text { Relative } \\
\text { Density }\end{array}$ & $\begin{array}{c}\text { Relative } \\
\text { Frequency }\end{array}$ \\
\hline 1 & Barilius pakistanicus (Mirza \& Sadiq, 1978) & - & 56 & - & 38 & - & - & 15.67 & 33.33 & 14.01 & 4.35 \\
\hline 2 & Barilius vagra (Hamilton, 1822) & - & 21 & - & 17 & - & - & 6.33 & 33.33 & 5.66 & 4.35 \\
\hline 3 & Tor putitora (Hamilton, 1822) & 8 & 7 & 4 & 6 & - & 2 & 4.5 & 83.33 & 4.02 & 10.87 \\
\hline 4 & Crossocheilus diplocheilus (Heckel, 1838) & 4 & 12 & 8 & 17 & 15 & 22 & 13 & 100 & 11.62 & 13.04 \\
\hline 5 & Garra gotyla (Gray, 1830) & 11 & 13 & 21 & 26 & 18 & 14 & 17.17 & 100 & 15.35 & 13.04 \\
\hline 6 & Schizothorax labiatus (McClelland, 1842) & 12 & 14 & 20 & 17 & 23 & 27 & 18.83 & 100 & 16.84 & 13.04 \\
\hline 7 & Schizothorax esocinus (Heckel, 1838) & - & - & - & - & - & 3 & 0.5 & 16.67 & 0.45 & 2.17 \\
\hline 8 & $\begin{array}{l}\text { Schizothorax } \\
\text { Plagiostomus (Heckel, 1838) }\end{array}$ & 18 & 22 & 26 & 36 & 15 & 24 & 23.5 & 100 & 21.01 & 13.04 \\
\hline 9 & & 6 & 8 & 11 & 3 & 5 & 9 & 7 & 100 & 6.25 & 13.04 \\
\hline 10 & Cyprinus carpio (Linnaeus, 1758) & 7 & 3 & 5 & 10 & 5 & 2 & 5.33 & 100 & 4.77 & 13.04 \\
\hline & Total & 66 & 156 & 95 & 170 & 81 & 103 & 111.83 & 766.66 & 99.99 & 99.98 \\
\hline
\end{tabular}




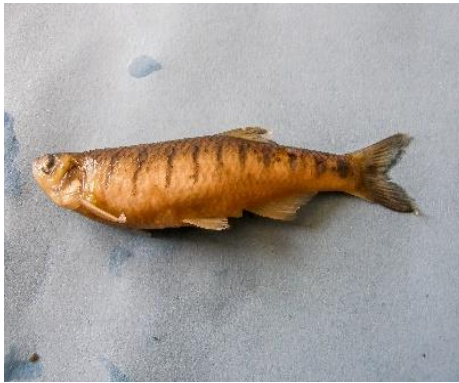

1. Barilius pakistanicus

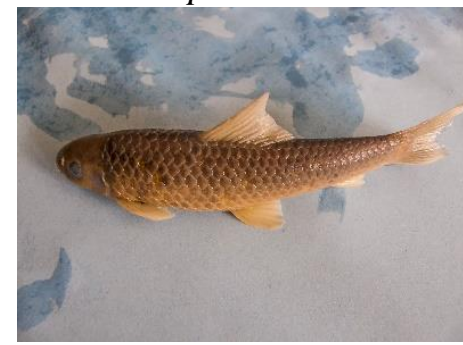

4.Crossocheilus diplocheilus

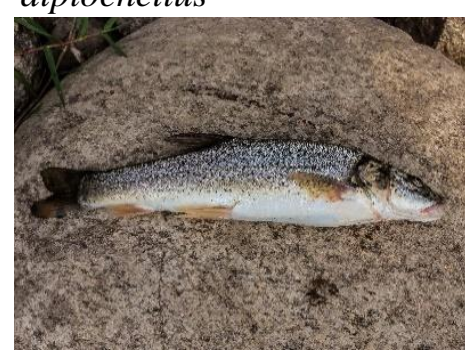

7. Shizothorax esocinus

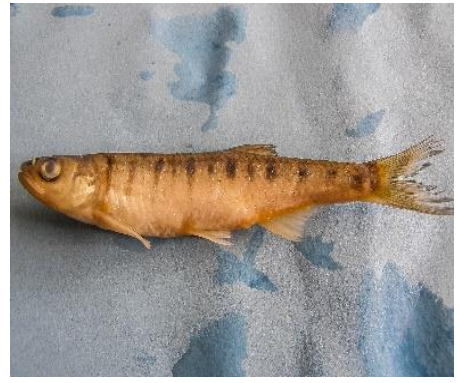

2. Barilius vagra

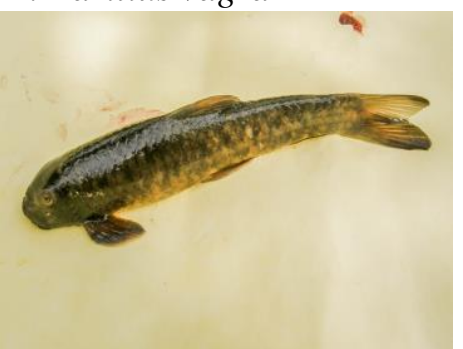

5.Garra gotyla

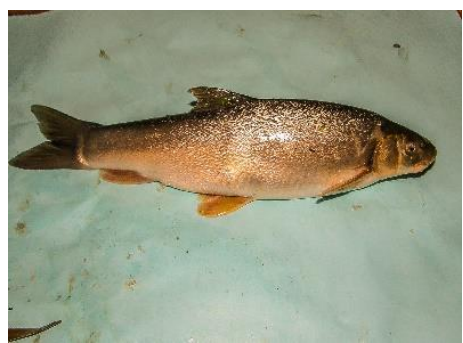

8. Schizothorax

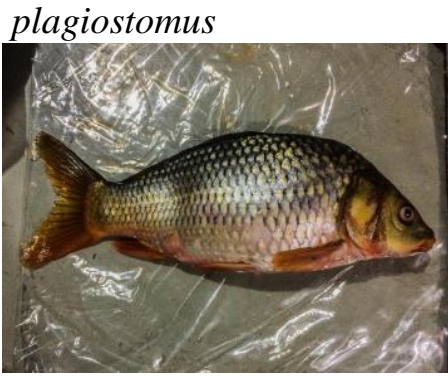

10. Cyprinus carpio

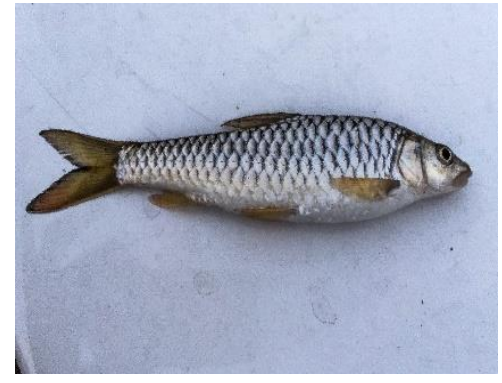

3. Tor putitora

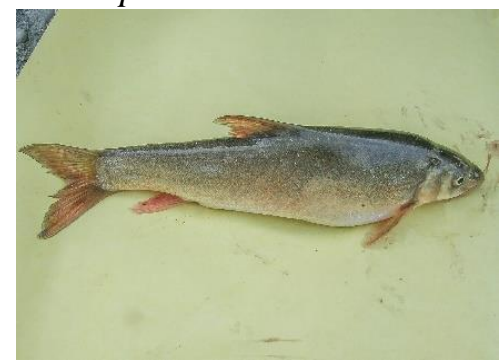

6. Schizothorax labiatus

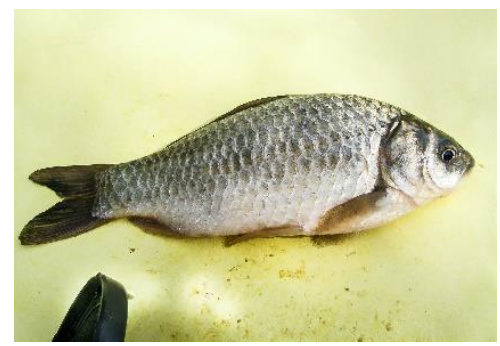

\section{Plate 1. Cyprinid fauna of River Panjkora, District Lower Dir, Pakistan}

\section{Conclusion}

During the present study, a total of 671 specimens belonging to 8 genera and 10 species of the family Cyprinidae were collected. Schizothorax Plagiostomus was found to be the most abundant species while Schizothorax esocinus was least found species in the study area. Rich faunal diversity of this area requires further explorations and documentations.

\section{Authors' contributions}

Conceived and designed the experiments: A Muhammad, Performed the experiments and analysed the data: A Wahab, Wrote the paper: A Muhammad \& A Wahab.

\section{Acknowledgement}

This research work is part of Doctoral research work of corresponding author Abdul Wahab. Authors are thankful to HED Khyber Pakhtunkhwa for financial 
assistance during the course of $\mathrm{Ph}$. D research.

\section{References}

1. Moyle PB \& Cech JJ (1996). Fishes: An Introduction to Ichthyology. $3^{\text {rd }}$ ed. Prentice-Hall, New Jersey. Pp. 67-122.

2. Hamilton F (1971). Importance of fish in fish encyclopaedia Brtinnica William Benton, London. 9: 1-1153.

3. Leveque C, Oberdorff T, Paugy D, Stiassny MLJ \& Tedesco PA (2008). Global diversity of fish (Pisces) in freshwater. Hydrobiology 595: 545567.

4. Wani, OA \& Gupta US (2015). A study on Ichthyofaunal diversity of Sagar Lake, Madhya Pradesh, India. Int J Biod \& Cons 7(3): 126-129.

5. Seethal. LS, Jaya DS \& Williams DrS (2013). Biodiversity Status of Fishes From

Vattakkayal, a Part of Ashtamudi Lake, Kollam District, Kerala, south India. International J of Scientific Research Publication 3 (12): 1-6.

6. Tesia, C \& Borodolai S (2012). Icthyofaunal diversity of Charju River, Arunachal Pradesh, India. Asian J Exp Biol Sci 1: 82-86.

7. Leunda PM (2010). Impacts of nonnative fishes on Iberian freshwater Ichthyofauna: current knowledge and gaps. Aquatic Invasions 5(3): 239-262.

8. Shrestha J, Singh DM \& Saund TB (2009). Fish diversity of Tamor River and its major tributaries of Eastern Himalayan region of Nepal. Nepal J Sci Tech 10: 219-223.

9. Baliarsingh BK, Kosygin L, Swain SK \& Nayak AK (2013). Species diversity and Habitat characteristics of fresh water fishes in the Similipal Bioshere Reserve, Odisha with some New Records. Biological Forum 5(2): 6470'.

10. Negi RK \& Mamgain S (2013). Species Diversity, Abundance and Distribution of Fish Community and Conservation Status of Tons River of Uttarkhand
State, India J Fisheries \& Aquatic Sciences 01: 1-10.

11. Olden JD, Kennard MJK \& Pusey BJ (2008). Species invasions and the changing biogeography of Australian freshwater fishes. Global Ecol Biogeogr 17: 25-37.

12. Bhuiyan AS, Islam MN \& Hossain MT (1992). A checklist of the fishes of Rajshahi. Rajshahi Univ Studies Part-B (20): 287-306.

13. Raghunathan MB (1989). A study on the fish fauna of Coorg District Karnataka. Zoological Survey of India, Western Ghat regional Station Calicut 26: 19-21.

14. Sharma CM \& Shrestha J (2001). Fish diversity and fishery resources of the Tinau river western Nepal. Environment and agriculture: Biodiversity, agriculture and pollution in South Asia. Pp. 78-83.

15. Sharma P (2014). Ichthyofaunal Diversity of Utterkhand, (Deprayag to Haridwar). Int J Edu Sci Res Rev 1(6): 43-49.

16. Verma R (2014). A study of Fish and Fisheries of River W. Ramganga from Central Himalaya, India. Species 7(17): 20-24.

17. Rafique M \& Khan NH (2012).

Distribution and status of significant freshwater fishes in Pakistan. Rec Zool Surv Pak 21: 90-95.

18. Khattak. RH, Aziz F, Rahman EU \& Zaidi F (2015). Ichthyofauna of River Kabul at Nowshehra, Khyber Pakhtunkhwa, Pakistan. Int J Fauna Biol Stu 2(2): 57-61.

19. Begum A \& Zehra A (2014). Ichthyofaunal diversity of Hub reservoir Sindh, Balochistan, Pakistan. Europe Acad Res 2(1): 341-353.

20. Mirza MR \& Mirza ZS (2014). Longitudinal Zonation in the Fish Fauna of the Indus River in Pakistan. Biologia 60(1), 149-152.

21. Mirza ZS, Mirza MR, Mirza M \& Sulehria AQK (2011). Ichthyofaunal 
diversity of the River Jhelum, Pakistan. Biologia 57(1\&1), 23-32.

22. Hasan Z, Ullah S \& Akhtar A (2015). Ichthyo-diversity of River Zhob, District Zhob, Balochistan. J Animal Plant Sci 25(3-2): 532-535.

23. Yousafzai AM, Khan W \& Hassan Z (2013). Fresh records on water quality and Ichthyodiversity of River Swat at Charsadda, Khyber Pakhtunkhwa. Pak J Zoo 45(6): 1727-1734.

24. Ishaq, M, Khan S, Khan J, Akhtar N \& Saeed K (2014). Study on Ichthyofaunal biodiversity of River Swat. World J Fish \& Mar Sci 6(4): 313-318

25. Hasan Z, Khan W, Khan MA, Rehman LU, Khan J \& Ullah S (2014). Comparative abundance of fish fauna of Different Streams of Bajaur Agency, Khyber Pakhtunkhwa, Pakistan. Biologia (Pakistan) 60 (1): 159-163.

26. Ullah S, Hassan Z \& Begum M (2014). The edible Icthyofauna of Konhaye stream District Dir Lower, Khyber Pakhtunkhwa. Pakhtunkhwa J Life Sci 2(03/04): 87-95.

27. Ahmad L, Saeed K, Khan S \& Akhtar N (2014). Ichthyofaunal Diversity of river Panjkora Upper Dir Khyber Pakhtunkhwa Pakistan. The $J$ of Zoology Studies. 1(6): 27-32.

28. Jayaram KC (1999). The fresh water fishes of the Indian region. Narendra Publishing House Delhi-110006 (India).

29. Mirza MR \& Sandhu AA (2007). Fishes of Punjab, Pakistan. Polymer Publications Urdu Bazar Lahore.

30. Jayaram KC. Cat fishes of India. 2006. Narendra Publishing House Dehli110006 (India).

31. Talwar TK \& Jhingram AG (1992). Inland Fishes of India. Rec Ind $J$ 3(2): 19-24.

32. Coad BW (2015). Native Fish Biodiversity in Afghanistan. Iran $J$ Ichthyol 2(40): 227-234.

33. Ali M, Husain S, Mahmood JA, Iqbal R \& Farooq A (2010). Fish diversity of freshwater bodies of Suleman Mountain Range, Dera Ghazi Khan Region, Pakistan. Pak J Zool 42(3), 285-289.

34. Iqbal Z, Pervaiz K \& Javed MN (2013). Population Dynamics of Tor macrolepis Teleostei: Cyprinidae) and other Fishes of Attock Region, Pakistan. Canadian. J Pure Appl Sci 7(1): 2195-2201.

35. Khan K (2011). Assessment and evaluation of adverse impacts of climatic changes on fresh water ecosystem and fish production in Kalpani stream in NWFP. A PhD thesis submitted to Pir Meher Ali Shah Arid Agriculture University, Rawalpindi.

36. Akhtar N, Khan S, Saeed K, Khan J, Khan BT \& Ahmad Z (2014). Fish fauna of River Arunai Matta Swat, Khyber Pakhtunkhwa, Pakistan. Europe Acad Res II (1): 147-153.

37. Saeed K, Khan S \& Haq F (2013). Diversity and population status of fish fauna of river Barandu District Buner Khyber Pakhtunkhwa, Pakistan. J Bio \& Env Sci 3(4): 83-88. .

38. Din A, Saeed K, Akhtar N, Khan A, Rafiq N \& Sher J (2016). Exploring the fish fauna of Chamla District Buner Khyber Pakhtunkhwa, Pakistan. Acad J Sci Res 4(8): 215-219.

39. Goswami UC, Basistha Sk, Bora D, Shyamkumar K, Sikia B \& Changsan K (2012). Fish diversity of Northeast India, inclusive of the Himalayan and Indo Burma biodiversity hotspots zone: A checklist on their taxonomic status, economic importance, geographical distribution, present status and prevailing threats. Int $J$ Biod Cons 4(15): 592-613.

40. Khajuria B \& Langer S (2016). Distribution records on abundance of Tor putitora in Jammu water. Int $J$ Fisheries Aqu Stu 4(1): 341-347.

41. Langer S, Tripathi NK \& Khajuria B (2013). Morphometric and meristic study of golden Mahaseer (Tor putitora) from Jhajjar stream (Jandk), 
India. Res J Anim Vet Fishery Sci 1(7): 1-4.

42. Pillai RS \& Yazdani GM (1977). Ichthyofauna of Garo Hills, Meghalaya (India). Rec Zool Surv India 72: 1-22.

43. Bhat FA, Balkhi MH, Najar AM \& Yousaf AR (2013). Distribution pattern, density and morphometric characteristics of Shizothoracines (Snow trout) in Lidder River, Kashmir. The Biosean 8(2): 363-379.

44. Rauf M, Din NU, Hasan Z, Haseeb A, Shah H \& Ullah S (2015). Ichthyofaunistic Study of River Kabul at Machini, Khyber Pakhtunkhwa, Pakistan. J Biol Env Sci 7(3): 186-194.

45. Sivakumar K (2008). Species richness, distribution pattern and habitat use of fishes in the Trans Himalaya, India. Elec J Ichthy 1: 31-42.

46. Mirza MR \& Hussain S (1998). A note on Chashma Lake, Pakistan, with records of Racoma labiate. McClelland (Pisces: Cyprinidae). Punjab Univ J Zool 13: 55-57.

47. Akhtar N, Saeed K \& Khan A (2016). Fish fauna of River Darmai Upper Swat
Khyber Pakhtunkhwa Pakistan. J Appl Environ Biol Sci 6(4S) 132-136.

48. Perveen F \& Uddin A (2015). The new record of Nangra fish, Nangra robusta Mirza and Awan (Siluriformes: Sisoridae: Sisorinae) from River Panjkora, Sheringal, Khyber Pakhtunkhwa, Pakistan. Int J Res St Zool 1(2): 21-28.

49. Mir FA, Mir JI, Patyal RS \& Chandra S (2013). Patterns of morphometric differentiation among three populations of snow-trouts, Shizothorax plagiostomus (Actinopterygei: Cypriniformis: Cyprinidae), from Kashmir Himalaya using a truss network system. Acta Icthyologica ET Piscatoria 43(4): 277-284.

50. Mirza MR (2006). A note on the fishes of Allai Khoar, NWFP. Punjab Univ J Zool 21(1-2): 72-75.

51. Khan AM, Shakir HA, Khan MN, Abid M \& Mirza MR (2008). Icthyofaunal survey of some fresh water reservoirs in Punjab. J Anim Sci 18(4): 151-154. 